\title{
Pengembangan Arsitektur Model Proses Bisnis Sekolah
}

\author{
Nuzulul Huda1, Eka Cahya Ningrum² ${ }^{2}$ Hilmi Tsaqif ${ }^{3}$, Muhammad Ainul Yaqin ${ }^{4}$ \\ 1,2,3,4Fakultas Sains dan Teknologi, UIN Maulana Malik Ibrahim Malang \\ 16650130@student.uin-malang.ac.id,16650016@student.uin-malang.ac.id, \\ 16650104@student.uin-malang.ac.id,yaqinov@ti.uin-malang.ac.id
}

\begin{abstract}
Determination of school business processes is very important in order to achieve the vision, mission, and goals of the school that has been determined, but many schools that run business processes do not follow the standards set by the national education standards body. Therefore there is a need for a business process that is in line with national education standards. The final results obtained from this study are in the form of architectural business process models from schools using the Togaf ADM method that can be used as a reference in conducting every business process in school.
\end{abstract}

Keywords: Bussiness Process, National Education Standards, Togaf ADM

\begin{abstract}
Abstrak
Penentuan proses bisnis sekolah sangat penting untuk mencapai visi, misi, dan tujuan sekolah yang telah ditentukan, tetapi banyak sekolah yang menjalankan proses bisnis tidak mengikuti standar yang ditetapkan oleh badan standar pendidikan nasional. Oleh karena itu diperlukan proses bisnis yang sejalan dengan standar pendidikan nasional. Hasil akhir yang diperoleh dari penelitian ini adalah dalam bentuk model proses bisnis arsitektur dari sekolah menggunakan metode Togaf ADM yang dapat digunakan sebagai referensi dalam melakukan setiap proses bisnis di sekolah.
\end{abstract}

Kata kunci: Proses Bisnis, Standar Nasional Pendidikan, Togaf ADM

\section{PENDAHULUAN}

Sebuah penetapan model proses bisnis merupakan hal yang sangat penting dalam sebuah institusi sekolah, yang mana dengan adanya model proses bisnis tersebut dapat menjadi acuan dari setiap elemen yang nantinya akan menjalankan berjalannya proses pendidikan di sebuah sekolah. Proses bisnis ialah serangkaian kegiatan yang dilakukan oleh pelaku usaha, mesin, dan / atau sistem informasi untuk mencapai tujuan bisnis. Tujuan bisnis harus merupakan tujuan yang dapat dioperasionalkan, Proses bisnis dapat dimodelkan dari yang berbeda perspektif yaitu dengan memodelkan aktor yang bertanggung jawab atas pelaksanaannya dan serangkaian kegiatan yang berada di bawah tanggung jawabnya, serta sumber daya yang terlibat dalam pelaksanaannya kegiatan [1]. Arsitektur model proses bisnis adalah sebuah model yang menggambarkan setiap proses bisnis yang ada dan dapat dijadikan patokan oleh setiap orang dengan memiliki satu standar sehingga dapat dengan mudah di gunakan oleh berbagai pihak terkait, menurut Togaf [2] menjelaskan bahwa Arsitektur Bisnis menggambarkan strategi produk dan/ atau jasa, dan organisasi, fungsional, proses, informasi, dan aspek geografis lingkungan bisnis.

Arsitektur model proses bisnis sekolah adalah sebuah model yang menggambarkan setiap proses bisnis yang ada di dalam mekanisme sekolah, dimulai dari perancangan visi misi hingga tujuan dari sebuah sekolah tersebut 
didirikan dan juga setiap detail proses bisnis yang ada di dalamnya. arsitektur model proses bisnis sekolah mengacu pada standar nasional pendidikan yang telah ditetapkan oleh Badan Standar Nasional Pendidikan sehingga setiap sekolah dapat menjalankan setiap proses bisnis sekolah sesuai standar yang telah ditetapkan. Arsitektur model proses bisnis sekolah ini sangat diperlukan guna untuk melakukan standarisasi dari setiap sekolah dan menciptakan kualitas pendidikan di sesuai standar yang telah ditetapkan oleh Badan Standar Nasional Pendidikan Sekolah sehingga setiap sekolah dapat mencapai tujuan sekolah tanpa keluar dari standar yang telah di tetapkan oleh Badan Standar Nasional Pendidikan dan menghasilkan lulusan yang memiliki kompetensi yang baik.

Arsitektur Proses adalah desain struktural dari sistem proses umum dan mencakup desain proses, logistik, kebijakan dan prosedur. Input, output, dan fungsi keseluruhan arsitektur proses juga ditentukan. Menjelaskan urutan, antarmuka, saling ketergantungan, dan hubungan lain di antara elemen proses dalam proses standar. Arsitektur proses juga menggambarkan antarmuka, saling ketergantungan, dan hubungan lain antara elemen proses dan proses eksternal. Arsitektur proses adalah deskripsi hirarkis dari proses skala besar, sub proses, dan aktivitas yang terjadi dalam suatu organisasi [3].

Secara umum arsitektur bisnis menggambarkan kumpulan aktivitas bisnis, data dan informasi yang ada dalam lingkungan internal dan eksternal organisasi. Arsitektur bisnis adalah representasi formal dan tools serta informasi bagi profesional bisnis organisasi dalam menilai, merubah, dan merancang bisnis [4]. Arsitektur bisnis juga menunjukkan relasi atau hubungan antara: aktivitas, kemampuan, fungsi, proses, waktu, urutan proses, sumber daya, orang, ketergantungan, kebutuhan, kolaborasi, organisasi, lokasi, batasan, data, sistem, peralatan, biaya, kontrol, keputusan, rules, keputusan, alur bisnis, aktivitas manual $\&$ otomatis, transaksi, perbedaan, dan kemungkinan.

Standar Nasional Pendidikan adalah kriteria minimal tentang sistem pendidikan di seluruh wilayah hukum Negara Kesatuan Republik Indonesia. Untuk menjamin mutu terselenggaranya pendidikan ditetapkan dalam Peraturan Pemerintah No 19 Tahun 2005 tentang Tentang Standar Nasional Pendidikan. Dalam merealisasikan PP 19 [6], secara operasional ditetapkan peraturan mentri yang berisi delapan standar pelaksanaan pendidikan di Indonesia yaitu :
a) Standar Isi
b) Standar Proses
c) Standar Kompetensi Lulusan
d) Standar Penilaian
e) Standar Pendidik dan Tenaga Kependidikan
f) Standar Sarana dan Prasarana
g) Standar Pengelolaan
h) Standar Pembiayaan Pendidikan 


\section{METODOLOGI PENELITIAN}

\subsection{Metode Togaf ADM}

TOGAF ADM merupakan metode generik berisikan sekumpulan aktivitas yang digunakan dalam memodelkan pengembangan arsitektur enterprise. Metode ini juga dapat digunakan sebagai panduan atau alat untuk merencanakan, merancang, mengembangkan dan mengimplementasikan arsitektur sistem informasi untuk organisasi. Architecture Development Method (ADM) merupakan metodologi lojik dari TOGAF yang terdiri dari 8 fase utama untuk pengembangan dan pemeliharaan technical architecturedari organisasi. ADM membentuk sebuah siklus yang iterative untuk keseluruhan proses, antar fase, dan dalam tiap fase di mana pada tiap-tiap keputusan baru harus diambil [5]. Prinsip arsitektur berarti merancang arsitektur system berdasarkan kebutuhan proses bisnis dan bagaimana mengimplementasikannya.

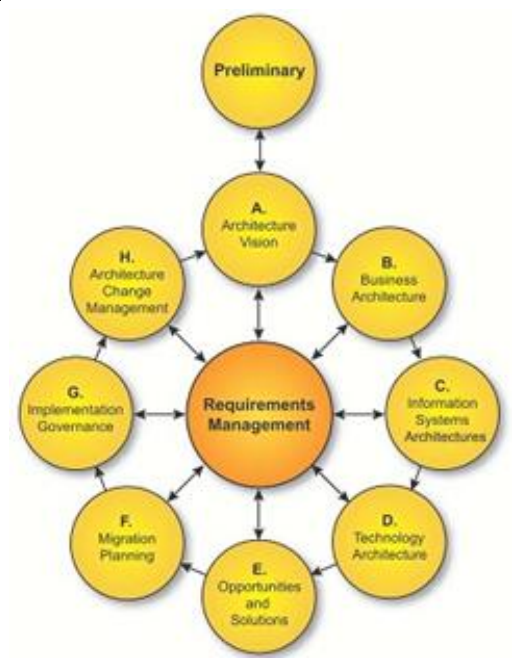

Gambar 1. Togaf ADM

\subsection{Pengumpulan Data}

Pengumpulan data dengan cara melihat sumber-sumber Dokumen terkait yakni dokumen tertulis maupun elektronik. Dokumen juga digunakan untuk mendukung kelengkapan data yang lain. Dalam penelitian ini sumber data yang digunakan peneliti ialah sumber data sekunder yang mana sumber tersebut berasal dari dokumen instrumen Standar Nasional Pendidikan (SNP) sesuai dengan Peraturan Pemerintah No 19 Tahun 2005 tentang Tentang Standar Nasional Pendidikan. Berikut adalah delapan Standar Pendidikan Nasional :
a) Standar Isi
b) Standar Proses
c) Standar Kompetensi Lulusan
d) Standar Pendidik dan Tenaga Kependidikan
e) Standar Sarana dan Prasarana
f) Standar Pengelolaan
g) Standar Penilaian
h) Standar Pembiayaan Pendidikan 


\subsection{Analisis Data}

Pada Standar Nasional Pendidikan (SNP) yang diadaptasi dari dokumen instrumen Standar Nasional Pendidikan (SNP) sesuai dengan Peraturan Pemerintah No 19 Tahun 2005 tentang Tentang Standar Nasional Pendidikan. Sebelum diolah menjadi model proses bisnis, terlebih dahulu dikelompokkan sesuai dengan Standar yang telah ditentukan oleh Badan Standar Nasional Pendidikan (BSNP) beserta instrumen instrumennya. Adapun pengelompokan dari delapan Standar Nasional Pendidikan yaitu :

1) Standar Isi

a. Pengembangan kurikulum

2) Standar Proses

a. Proses kegiatan belajar mengajar

3) Standar Kompetensi Lulusan

4) Standar Penilaian

a. Penilaian pendidik

b. Penilaian satuan pendidikan

c. Penilaian oleh pemerintah

5) Standar Pendidik Dan Tenaga Kependidikan
a. Standar guru
b. Standar kepala sekolah
c. Standar tenaga administrasi
d. Standar tenaga perpustakaan
e. Standar tenaga laboratorium
f. Standar tenaga layanan kusus

6) Standar Sarana Dan Prasarana
a. Standar lahan
b. Standar bangunan
c. Standar kelengkapan sarana dan prasarana

7) Standar Pengelolaan
a. Penentuan visi, misi dan tujuan
b. Pengembangan rencana kerja sekolah
c. Pedoman akademik sekolah
d. Kalender akademik sekolah
e. Struktur organisasi sekolah
f. Kepemimpinan

8) Standar Pembiayaan
a. Biaya investasi
b. Biaya operasional
c. Biaya personal

\subsection{Perancangan Model Proses Bisnis}

Pada tahapan ini dilakukan perancangan proses-proses bisnis yang terkait langsung dengan penerapan Standar Nasional Pendidikan (SNP). Sehingga dibuatlah standar operasional prosedur (SOP) dari setiap proses bisnis tersebut, 
dan dari setiap standar operasional prosedur (SOP) dibuatlah proses bisnis dengan menggunakan BPMN (Business Process Modeling Notation).

Perancangan model proses ini dibuat berdasarkan pada Standar Nasional Pendidikan (SNP) yang diadaptasi dari dokumen instrumen Standar Nasional Pendidikan (SNP) sesuai dengan Peraturan Pemerintah No 19 Tahun 2005 tentang Tentang Standar Nasional Pendidikan.

\section{HASIL DAN PEMBAHASAN}

Pengembangan arsitektur proses bisnis sekolah didasarkan pada semua prosedur proses bisnis yang ada dalam sekolah, sesuai dengan bagan pada Gambar 2 yang mana sekolah harus mentukan visi terlebih dahulu sebelum merumuskan misi dan tujuan nya, untuk mencapai tujuan tersebut sekolah menjalankan proses bisnis sesuai delapan standar yang telah ditentukan Badan Standar Nasional Pendidikan (BNSP). Dengan menggunakan metode Togaf ADM prosedur dari setiap proses bisnis tersebut dimodelkan dalam bentuk BPMN (Business Process Model and Notation).

Agenda yang harus dilakukan sekolah yang pertama kali adalah menentukan visi dari sekolah itu sendiri dilanjutkan dengan merumuskan misi dan tujuan sekolah berdasarkan visinya, Setelah visi, misi dan tujuan dirumuskan, maka untuk mencapai ketiga hal tersebut sekolah perlu merumuskan proses bisnis apa saja yang harus ada didalamnya, ada banyak proses bisnis yang harus dijalankan oleh sekolah yang terbagi dalam agenda besar diantaranya agenda tahunan, agenda semesteran dan agenda harian untuk agenda sekolah yang terdiri dari :

a) Agenda tahunan

1) Penyusunan rencana kerja sekolah (RKS)

2) Pengelolaan biaya SPP

3) Pengelolaan biaya gaji guru

4) Pengelolaan biaya investasi

5) Pengelolaan tenaga pendidik dan kependidikan

6) Pengembangan kurikulum

7) Penetapan kompetensi kelulusan minimal

b) Agenda semsteran

1) Penngelolaan SPP

2) Pengelolaan sarana dan prasarana

3) Pengelolaan penilaian peserta didik

c) Agenda harian

Proses belajar mengajar

Berdasar agenda agenda yang telah dirumuskan maka terbentuklah beberapa proses bisnis yang kita buat menggunakan BPMN yaitu terdapat:

1) Bisnis proses pengelolaan sarana dan prasarana yang mana bisnis proses ini terlebih dahulu harus ada dan sudah sesuai standar yang telah ditetapkan oleh Badan Standar Nasional Pendidikan sesuai dengan Gambar 2 
2) Bisnis proses pengelolaan sekolah yang mencakup penyusunan Rencana Kerja Sekolah, penentuan besaran SPP, penentuan gaji guru dan penentuan biaya investasi sekolah sesuai dengan Gambar 3.

3) Bisnis proses pengelolaan pendidik dan tenaga kependidikan yang mencakup proses perekrutan pendidik dan tenaga kependidikan hingga proses pensiunnya pendidik dan tenaga pendidikan sesuai dengan Gambar 4.

4) Bisnis proses perumusan kurikulum yaitu bisnis proses yang menentukan sebuah sekolah menggunakan kurikulum dengan model kurikulum yang telah disepakati sesuai dengan kondisi sekolah sesuai dengan Gambar 5.

5) Bisnis proses kegiatan belajar mengajar yaitu bisnis proses yang mencakup dari proses pendaftaran peserta didik, penilaian yang sesuai dengan standar kompetensi lulusan hingga proses kelulusan peserta didik sesuai dengan Gambar 6.

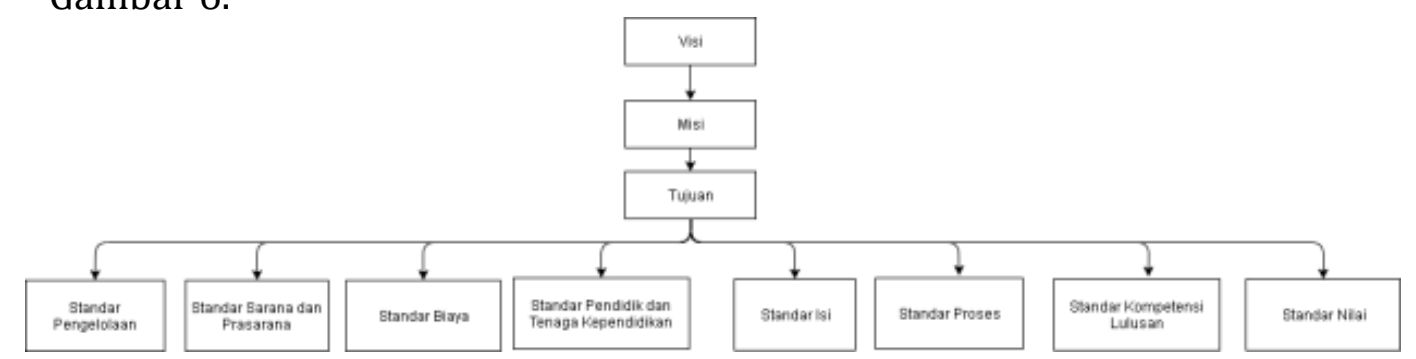

Gambar 2. Bagan proses bisnis sekolah

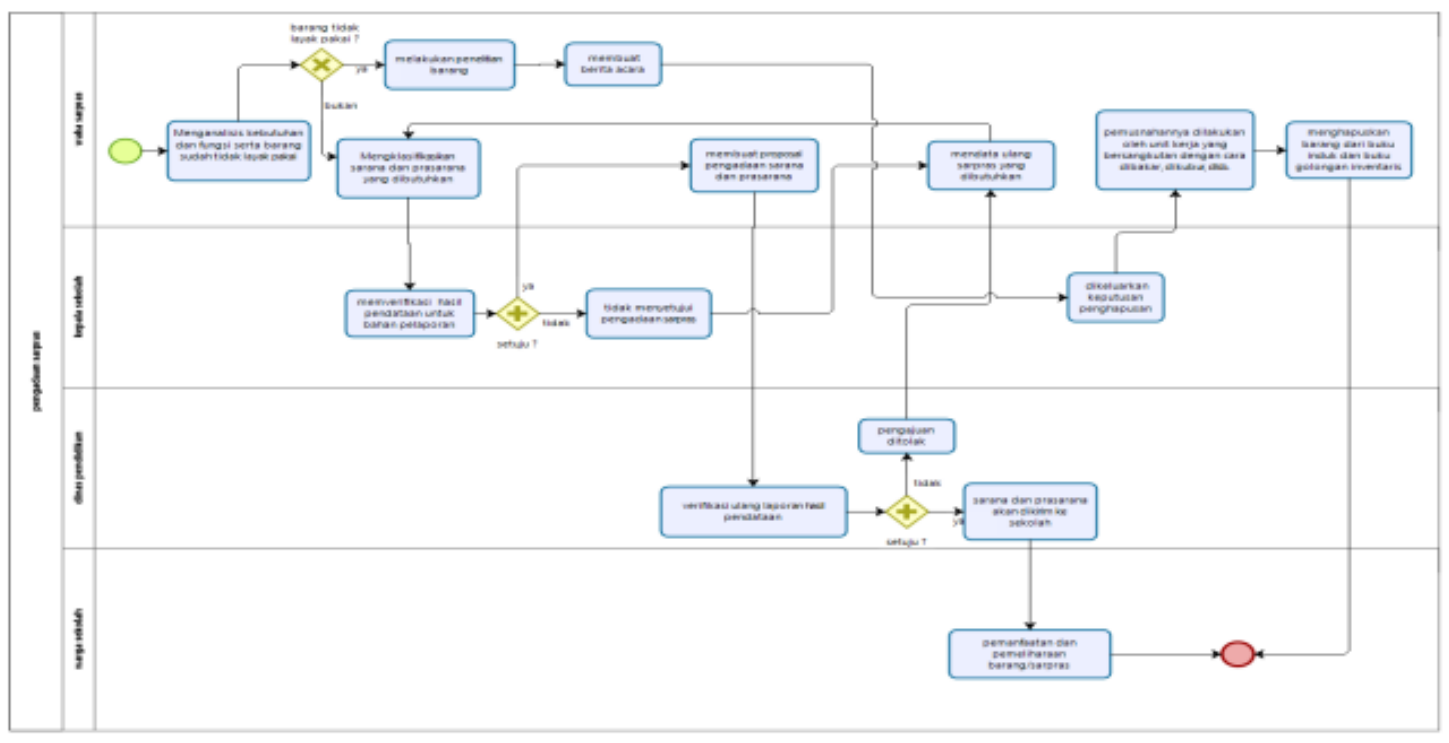

Gambar 3. Standar Operasional Prosedur (SOP) Pengelolaan Sarana dan Prasarana 
Jurnal Riset Sistem Informasi Dan Teknik Informatika (JURASIK)

Volume 5 Nomor 2 Agustus, pp 166-174

ISSN: 2527-5771/EISSN: 2549-7839

https://tunasbangsa.ac.id/ejurnal/index.php/jurasik

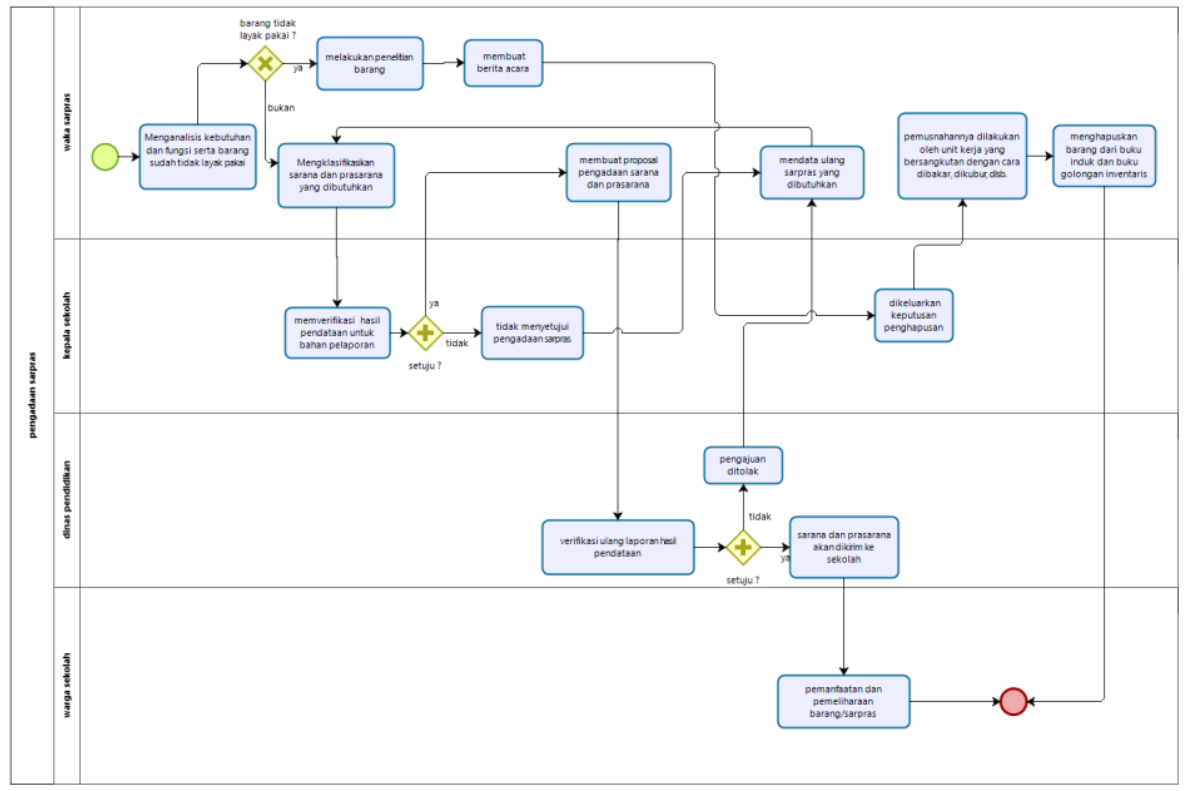

buzis

Gambar 4. Standar Operasional Prosedur (SOP) Pengelolaan Sekolah

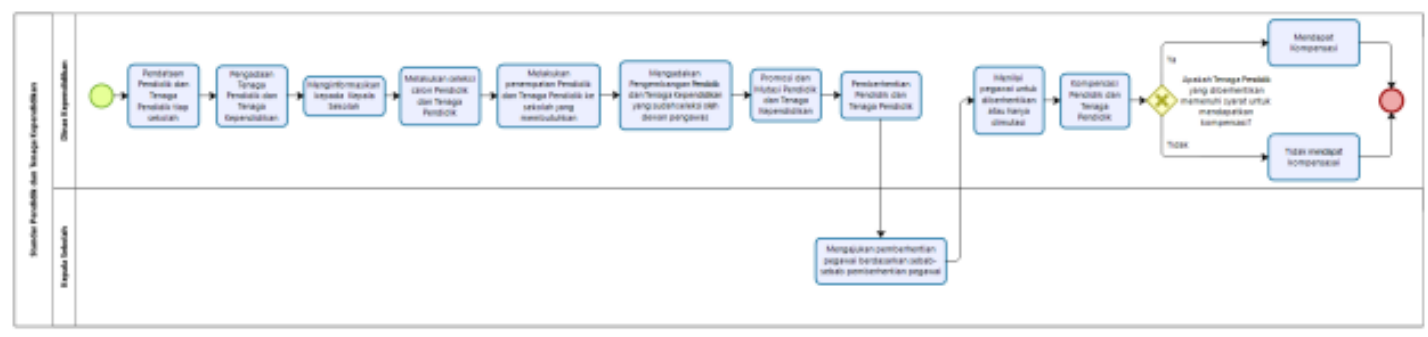

Gambar 5. Standar Operasional Prosedur (SOP) Pengelolaan Pendidik dan Tenaga Kependidikan

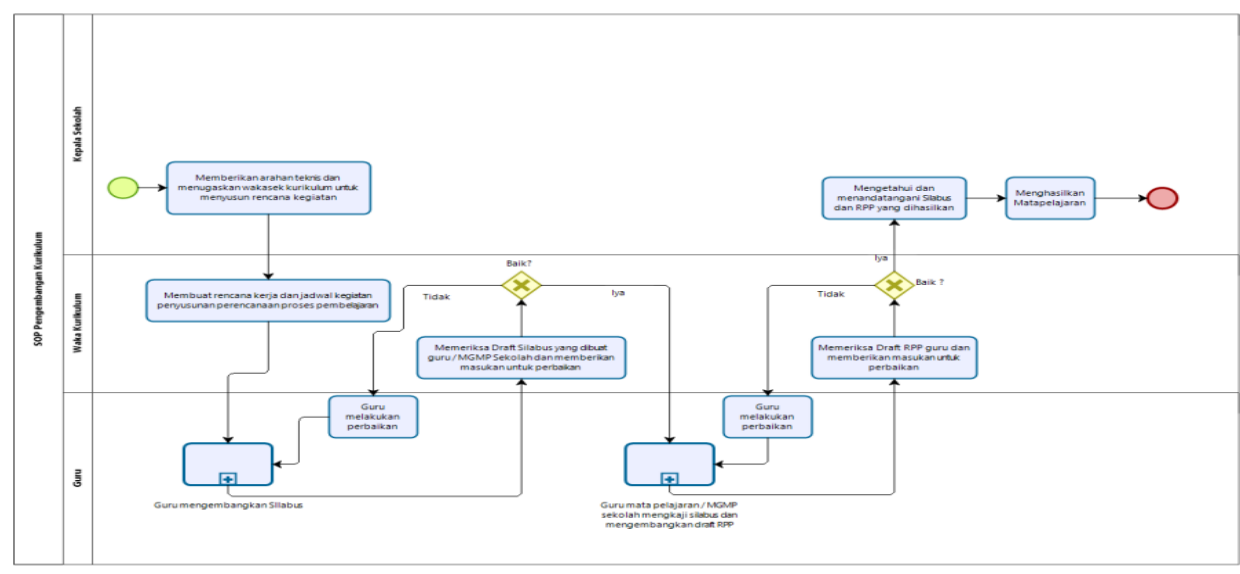

Gambar 6. Standar Operasional Prosedur (SOP) Pengembangan Kurikulum 


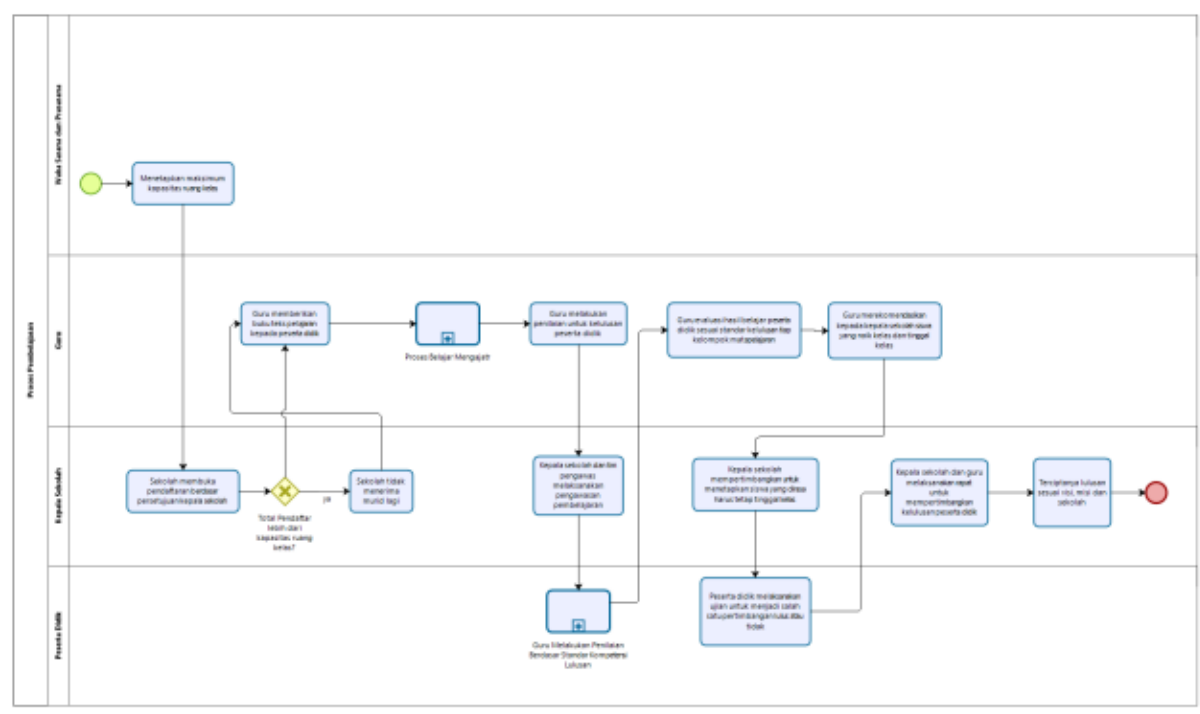

Gambar 7. Standar Operasional Prosedur (SOP) Kegiatan Belajar dan Mengajar

Berikut adalah tabel kesesuaian proses bisnis dengan Standar Nasional Pendidikan yang telah ditetapkan oleh Badan Standar Nasional Pendidikan sesuai pada Tabel 1.

Tabel 1. Kesesuaian Proses Bisnis dengan Standar Nasional Pendidikan

\begin{tabular}{|l|c|c|c|c|c|c|c|c|}
\hline \multicolumn{1}{|c|}{ SOP } & \multicolumn{7}{|c|}{ Standar } \\
\cline { 2 - 8 } & 1 & 2 & 3 & 4 & 5 & 6 & 7 & 8 \\
\hline $\begin{array}{l}\text { Standar Operasional Prosedur } \\
\text { (SOP) Pengelolaan Sarana dan } \\
\text { Prasarana }\end{array}$ & & & & & $\sqrt{ }$ & & & \\
\hline $\begin{array}{l}\text { Standar Operasional Prosedur } \\
\text { (SOP) Pengelolaan Sekolah }\end{array}$ & & & & & & $\sqrt{ }$ & & $\sqrt{ }$ \\
\hline $\begin{array}{l}\text { Standar Operasional Prosedur } \\
\text { (SOP) Pengelolaan Pendidik dan } \\
\text { Tenaga Kependidikan }\end{array}$ & & & & $\sqrt{ }$ & & & & \\
\hline $\begin{array}{l}\text { Standar Operasional Prosedur } \\
\text { (SOP) Pengembangan Kurikulum }\end{array}$ & $\sqrt{ }$ & & & & & & & \\
\hline $\begin{array}{l}\text { Standar Operasional Prosedur } \\
\text { (SOP) Kegiatan Belajar dan } \\
\text { Mengajar }\end{array}$ & & $\sqrt{ }$ & $\sqrt{ }$ & & & & $\sqrt{ }$ & \\
\hline
\end{tabular}

\section{SIMPULAN}

Dari hasil penelitian yang telah dilakukan dapat disimpulkan bahwa kita dapat memodelkan setiap bisnis sekolah yang telah kita rumuskan setelah penetapan sebuah visi, misi dan tujuan sekolah dengan menggunakan BPMN 
Jurnal Riset Sistem Informasi Dan Teknik Informatika (JURASIK)

Volume 5 Nomor 2 Agustus, pp 166-174

ISSN: 2527-5771/EISSN: 2549-7839

https://tunasbangsa.ac.id/ejurnal/index.php/jurasik

sehingga proses bisnis yang kita buat memiliki standar yang dpaat dipahami oleh berbagai pihak yang terkait.

\section{DAFTAR PUSTAKA}

[1] Montilva \& Barrios. 2004. "BMM: A Business Modeling Method For Information System Development". CLEI Electronic Journal

[2] https://pubs.opengroup.org/, Information System Architecture. Diakses pada 20 November 2019

[3] Mehdi Khosrow-Pour. 2008. "Encyclopedia of Information Science and Technology, Second Edition". Igi Global.

[4] Yunis, R., Surendro, Telaumbanua. 2010. "Arsitektur Bisnis: Pemodelan Proses Bisnis Dengan Object Oriented". Seminar Nasional Informatika 2010 (semnasIF 2010) UPN "Veteran" Yogyakarta

[5] Rizky, N., Fitroh, Firmansyah, A. F., 2017. "Perencanaan Arsitektur Enterprise Menggunakan Togaf ADM Versi 9(Studi Kasus : Bimbel Salemba Group". Studia Informatika

[6] Pemerintah Indonesia. 2013. Undang Undang No. 32 Tahun 2013 perubahan atas Undang Undang No. 19 Tahun 2005 tentang Tentang Standar Nasional Pendidikan. Lembaran RI Tahun 2013 No. 32. Jakarta : Sekretariat Negara 